\title{
Erratum: Rapid analysis of T-cell selection in vivo using T cell-receptor retrogenic mice
}

Jeff Holst, Kate M Vignali, Amanda R Burton \& Dario A A Vignali

Nature Methods 3, 191-197 (2006); published online 17 February 2006; corrected after print 1 March 2006.

In the version of this article initially published, the name of one of the receptors mentioned in the abstract was incorrectly stated as OY-II क instead of OT-II. The correct sentence is: "We demonstrate that these retrogenic mice are comparable to transgenic mice expressing three commonly used TCRs (OT-I, OT-II and AND)."

This error has been corrected in the HTML and PDF versions of the article. 